\title{
Comparison of Effects of Different Enzymic Levels Immnowall and Premalac Indices of Growth, Survival Rate and Body Composition in Cyprinus carpio
}

\author{
Abbas Barari ${ }^{1 *}$, Mazdak Pakzad Sorki ${ }^{1}$, Rajab Mohammad Nazari ${ }^{1}$ \\ ${ }^{1}$ Propagation Center, Breeding and Restocking Fish Shahid Rajai Sari, Iran \\ Corresponding author Address: Abbasbarari812@gmail.com
}

\begin{abstract}
This study was undertaken to evaluate the effects of Immnowal and Premalac on feed intake, weight gain, food conversation ratio, specific growth rate, total length and survival of juvenile Common carp For this purpose, 300 fish were stocked in three replications at the VENIRO tanks and fed twice daily by $0,0.5,1$ and $1.5 \mathrm{~g} / \mathrm{Kg}$ of Immnowall and $0.5,1$ and $1.5 \mathrm{~g} / \mathrm{Kg}$ of premalac for 8 weeks. Results show that Growth factors including: Weight gain, specific growth rate, growth rate, feed conversion ratio and body weight index for fish administrated by 0.15 percent Immnowall showed a statistical significant differences $(P<0.05)$ by control. Protein rate increase in probiotic treatment ( 4,5 and 6 with $0.05,0.1$ and 0.15 percent premalak in diet) of carcass analysis and showed a statistical significant differences $(P<0.05)$ by control. Moreover, fish fed by 0.1 percent Immnowall, 0.05 percent Premalac and 0.15 percent Premalac multienzyme showed a significant difference $(P<0.05)$ in higher survival rate than control.
\end{abstract}

Keywords: Common Carp, Immnowall, Premalac, growth indices, survival, body Composition

\section{Introduction}

According to the Ministry of Agriculture's policy, Iran Fisheries Organization in Northern provinces in Iran (Mazandaran, Gilan and Golestan) must produce 300 million carp fry restocking the Caspian Sea annually (Afshar mazandaran, 2003). According to the importance of common carp for fishermen and the local economy, It is imperative that a solution be considered to reduce almost 40 percent mortality in larvae reared to fingerling stage of common carp (Emedi, 1985).

High mortality is a problem in fish larvae culture therefore; successful production of fish depends on the availability of suitable food that can be caused health healthy and growth especially in the larval stage (Girri et al., 2002). Accordingly the additives such as probiotics and prebiotics the widely used, as active ingredients in maintaining and improving the intestinal microbial balance are essential for maintaining healthy fish (Fuller, 1989). In order to reduce mortality in the larvae to fry can be used probiotics premalac (Verschuere et al. 2000) or prebiotic Immunowall that immune simulating )Peng and Gatlin, 2003) as supplements.

Probiotics in aquaculture have been shown to have several modes of action: competitive exclusion of pathogenic bacteria through the production of inhibitory compounds; improvement of water quality; enhancement of immune response of host species and enhancement of nutrition of host species through the production of supplemental digestive enzymes (Verschuere, et al. 2000).

For this reason, numerous attempts have been made to enhance feed intake, growth performance, and health parameters of fish and shrimp through the incorporation of probiotics and prebiotics in feed (Verschuere, et al. 2000; Peng and Gatlin, 2003; Girri et al., 2002).

The present study was conducted to evaluate the effect of immnowal and premalac on feed intake, weight gain, food conversation ratio, specific growth rate, total length and survival of juvenile common carp (Cyprinus carpio L).

\section{Materials and Methods}

\section{Experimental design}

This study was conducted in Propagation Center, breeding and restocking fish Shahid Rajai Sari (Iran) from early April to late June 2010.

Water quality parameters such as temperature, $\mathrm{pH}$ and dissolved oxygen were measured daily by Thermometer, pHmeter (Model WTW330I) and oxygen meter (Model WTW320I), respectively. They were kept under optimal range.

2100 larvae Caspian Sea carp $0.595 \pm$ 0/006 g weights were obtained from Shahid Rajai Sari, Iran. In this study, 21 fiberglass tanks $(200 \times 200 \times 60 \mathrm{~cm})$ with air pump for each tank (500-L) were designed. After 14 days of acclimation, Larvae were distributed into 6 treatments tanks (100 larval per tank) (treatment 1-6), and 1 tank as control, Three replicates were maintained for each treatment as follows:

Control $=$ SFC diet (no probiotic and/or prebiotic), treatment $1=$ SFC diet $+0 / 05 \%$ Immnowall, treatment $2=$ SFC diet + 0/1\% Immnowall, treatment 3= SFC diet+ 0/15\% Immnowall, treatment $4=$ SFC diet $+0 / 05 \%$ premalac, treatment $5=$ SFC diet $+0 / 1 \%$ premalac, and treatment $6=$ SFC diet $+0 / 15 \%$ premalac. 


\section{International Journal of Science and Research (IJSR) \\ ISSN (Online): 2319-7064 \\ Index Copernicus Value (2013): 6.14 | Impact Factor (2015): 6.391}

Biochemical analysis on SFC diet showed that it contained $8 / 8 \%$ moisture, $11 / 36 \%$ ash, $34 / 5 \%$ crud protein and $10 / 7 \%$ fat.

The fry were fed 2 times a day (8:00 am and 3:00 pm) at $10 \%$ of body weight for a period of 8 weeks (from early April 2010 to late June 2010).

\section{Growth Performance}

During the experiment, weight and length of 20 Fish in each tank was monitored once every 2 weeks following a 12-h starvation until the end of experiment.

Growth performance and survival rate of the Caspian roach fry were calculated using the following Formula: FCR (Feed conversion ratio) $=\mathrm{F} /(\mathrm{Bt}-\mathrm{B} 0)$; SGR \% d-1 $($ Specific growth rate $)=($ Ln Wt - Ln W0 $) \times 100 / t$ (Ronyai et al.1990); BWI\% (Body Weight Increase) = $(\mathrm{Wt}-$ $\mathrm{W} 0) / \mathrm{W} 0 \times 100 ; \mathrm{GR}\left(\right.$ gr d $\left.^{-1}\right)$ (Growth rate) $=(\mathrm{Wt}-\mathrm{W} 0) / \mathrm{n}$; $\mathrm{CF}$ or $\mathrm{K}$ (Condition factor) $=100 \times\left(\mathrm{Wt} / \mathrm{TL}^{3}\right)$; Survival rate $=100 \times(\mathrm{Nt} / \mathrm{N} 0)($ Hung et al.,1989) .

Where: F: relative food intake (g), Bt and B0: final and initial fish biomass (g); Wt and W0: final and initial body weight (g); t: time of rearing (days); TL: total length; Nt and N0: final and initial fish number.

\section{Body Composition}

Fish samples were analyzed for proximate composition according to AOAC (1992). 20 fish from each tank of experimental treatments were taken for chemical analysis of body composition. Sampled fish were killed and the viscera were removed and the carcasses stored at $-18^{\circ} \mathrm{C}$ in fridge for chemical analyses. Moisture content (at $105^{\circ} \mathrm{C}$ for 24h), crude protein content (Kjeldahl apparatus, model BAP40, Germany. Nitrogen* 6.25), crude fat content (extraction with petroleum ether by Soxhlet apparatus, model BOHR, Germany) and ash (incineration at $550^{\circ} \mathrm{C}$ for $6 \mathrm{~h}$ ) of the samples were determined according to AOAC (1992).

\section{Data analysis}

All data are shown as mean \pm SD (standard deviations). Normality of data was tested by Shapiro-Wilk's test. Data were subjected to one-way ANOVA and significant difference between the treatments was determined by
Duncan's test. The values of $\mathrm{P}<0 / 05$ were considered significantly different. All analyses were performed using statistical software SPSS (version, 17) and Excel.

\section{Result}

The water quality parameters are presented in Table 1 . There was no significant difference in water quality parameters among treatments during the experiment $(\mathrm{P}>0.05)$.

Table 1: water quality parameters during the experiment

\begin{tabular}{|c|c|c|c|}
\hline & mean & Max & $\min$ \\
\hline O2 $(\mathrm{mg} / \mathrm{l})$ & $9.09 \pm 0.06$ & 10.1 & 8.3 \\
\hline Temperature $\left({ }^{\circ} \mathrm{C}\right)$ & $23.61 \pm 0.2$ & 24.8 & 21.6 \\
\hline $\mathrm{pH}$ & - & 8.3 & 7.9 \\
\hline
\end{tabular}

Average weight and total length of carp larval in different treatment are presented in Table 2. There was significant difference detected among different treatment groups in average weight and total length $(\mathrm{P}<0.05)$. Also, there was significant difference detected among treatment 2, 3, 4, 5 and 6 in weight and treatment 2, 3, 5 and 6 in total length $(\mathrm{P}<$ $0.05)$.

Table 2: average weight and total length of carp larval in different treatment

\begin{tabular}{|c|c|c|}
\hline & Weight (mg) & Total length $(\mathrm{cm})$ \\
\hline Control & $1186.00 \pm 0.06^{\mathrm{a}}$ & $5.50 \pm 0.00^{\mathrm{a}}$ \\
\hline Treatment 1 & $1199.00 \pm 0.08^{\mathrm{ab}}$ & $5.50 \pm 0.00^{\mathrm{a}}$ \\
\hline Treatment 2 & $1220.00 \pm 0.07^{\mathrm{c}}$ & $5.57 \pm 0.04^{\mathrm{bc}}$ \\
\hline Treatment 3 & $1289.00 \pm 0.06^{\mathrm{f}}$ & $5.70 \pm 0.00^{\mathrm{d}}$ \\
\hline Treatment 4 & $1212.00 \pm 0.07^{\mathrm{bc}}$ & $5.54 \pm 0.04^{\mathrm{ab}}$ \\
\hline Treatment 5 & $1238.00 \pm 0.07^{\mathrm{d}}$ & $5.60 \pm 0.00^{\mathrm{c}}$ \\
\hline Treatment 6 & $1256.00 \pm 0.01^{\mathrm{e}}$ & $5.67 \pm 0.02^{\mathrm{d}}$ \\
\hline \multicolumn{3}{|c|}{ Values with different superscript letters denote } \\
significantly different means within each column \\
$(\mathrm{P}<0.05)$. \\
\hline
\end{tabular}

The results showed the highest survival in carp larval was observed in treatments 2, 4 and 6 and the lowest survival was detected in control group. The lowest and highest FCR was detected in treatment 3 and control, respectively. The result showed that there was significant difference in SGR, BWI and GR among all treatments $(\mathrm{P}<0.05)$ (Table 3$)$.

Table 3: Growth performance of carp larval in different treatment.

\begin{tabular}{|c|l|l|l|l|l|l|}
\hline & FCR (\%) & SGR (\%) & BWI (\%) & GR (g/day) & CF (g/cm) & Survival (\%) \\
\hline Control & $1.54 \pm 0.06^{\mathrm{c}}$ & $2.23 \pm 0.02^{\mathrm{a}}$ & $38 / 49 \pm 0.04^{\mathrm{a}}$ & $23.52 \pm 0.02^{\mathrm{a}}$ & $0.71 \pm 0.01^{\mathrm{bc}}$ & 83.66 \\
\hline Treatment 1 & $1.49 \pm 0.02^{\mathrm{bc}}$ & $2.49 \pm 0.09^{\mathrm{ab}}$ & $41.78 \pm 0.02^{\mathrm{ab}}$ & $25.23 \pm 0.09^{\mathrm{ab}}$ & $0.72 \pm 0.01 \mathrm{bc}$ & 86.66 \\
\hline Treatment 2 & $1.48 \pm 0.02^{\mathrm{b}}$ & $2.56 \pm 0.09^{\mathrm{b}}$ & $43.20 \pm 0.02^{\mathrm{b}}$ & $26.28 \pm 0.01^{\mathrm{bc}}$ & $0.70 \pm 0.01^{\mathrm{ab}}$ & 88.00 \\
\hline Treatment 3 & $1.42 \pm 0.06^{\mathrm{a}}$ & $2.89 \pm 0.02^{\mathrm{c}}$ & $49.92 \pm 0.03^{\mathrm{c}}$ & $30.66 \pm 0.02^{\mathrm{d}}$ & $0.60 \pm 0.00^{\mathrm{ab}}$ & 87.33 \\
\hline Treatment 4 & $1.50 \pm 0.02^{\mathrm{bc}}$ & $2.46 \pm 0.01^{\mathrm{ab}}$ & $41.26 \pm 0.02^{\mathrm{ab}}$ & $25.28 \pm 0.01^{\mathrm{ab}}$ & $0.71 \pm 0.02^{\mathrm{c}}$ & 87.66 \\
\hline Treatment 5 & $1.47 \pm 0.03^{\mathrm{b}}$ & $2.61 \pm 0.01^{\mathrm{b}}$ & $44.40 \pm 0.02^{\mathrm{b}}$ & $27.59 \pm 0.01^{\mathrm{c}}$ & $0.68 \pm 0.00^{\mathrm{a}}$ & 88.00 \\
\hline Treatment 6 & $1.54 \pm 0.06^{\mathrm{c}}$ & $2.32 \pm 0.02^{\mathrm{a}}$ & $38.49 \pm 0.04^{\mathrm{a}}$ & $23.52 \pm 0.02^{\mathrm{a}}$ & $.071 \pm 0.01^{\mathrm{bc}}$ & 83.66 \\
\hline
\end{tabular}

Body composition analysis of carp larval show that there was significant difference detected among different treatment groups and between any treatments and control group in Moisture, Ash, crud Protein and fat $(\mathrm{P}<0.05)$ (Table 4). There was no significant difference detected between treatments 1, 2 and control group in crud Protein $(\mathrm{p}>0 / 05)$. 


\section{International Journal of Science and Research (IJSR) \\ ISSN (Online): 2319-7064 \\ Index Copernicus Value (2013): 6.14 | Impact Factor (2015): 6.391}

Table 4: body composition of carp larval in different treatment

\begin{tabular}{|c|c|c|c|c|}
\hline & $\begin{array}{c}\text { Moisture } \\
(\%)\end{array}$ & Ash (\%) & $\begin{array}{c}\text { Protein } \\
(\%)\end{array}$ & $\begin{array}{c}\text { fat } \\
(\mathrm{g} / \mathrm{day})\end{array}$ \\
\hline Control & $23.68^{\mathrm{ab}}$ & $13.91^{\mathrm{a}}$ & $58.81^{\mathrm{a}}$ & $14.35^{\mathrm{ab}}$ \\
\hline Treatment 1 & $24.24^{\mathrm{a}}$ & $14.11^{\mathrm{a}}$ & $60.81^{\mathrm{a}}$ & $17.71^{\mathrm{a}}$ \\
\hline Treatment 2 & $23.33^{\mathrm{c}}$ & $15.89^{\mathrm{ab}}$ & $60.81^{\mathrm{a}}$ & $21.06^{\mathrm{c}}$ \\
\hline Treatment 3 & $23.07^{\mathrm{abc}}$ & $18.15^{\mathrm{a}}$ & $61.73^{\mathrm{ab}}$ & $20.54^{\mathrm{bc}}$ \\
\hline Treatment 4 & $25.28^{\mathrm{bc}}$ & $12.63^{\mathrm{ab}}$ & $62.35^{\mathrm{b}}$ & $18.39^{\mathrm{bc}}$ \\
\hline Treatment 5 & $25 \mathrm{ab}^{\mathrm{c}}$ & $13.15^{\mathrm{c}}$ & $62.88^{\mathrm{b}}$ & $16.58^{\mathrm{bc}}$ \\
\hline Treatment 6 & $23.2^{\mathrm{ab}}$ & $10.15^{\mathrm{bc}}$ & $63.74^{\mathrm{b}}$ & $17.59^{\mathrm{c}}$ \\
\hline \multicolumn{5}{|c|}{ Values with different superscript letters denote significantly } \\
different means within each column (P<0.05). \\
\hline
\end{tabular}

\section{Discussion}

It has been demonstrated experimentally that probiotics indeed may enhance the growth of fish. Most probiotics colonize the host and affect the digestive processes through increased numbers and production of microbial enzymes, improving the intestinal microbial balance and consequently the digestibility and absorption of feed and feed utilization (El Haroun et al., 2006; Mohapatra et al., 2012). Prebiotics mainly consist of oligosaccharides promoting beneficial bacterial growth within the GI tract (Gibson et al., 2003). Gibson et al. (2004) suggested that a prebiotic has to resist gastric acidity, hydrolysis by (mammalian) enzymes and GI absorption, be fermented by the intestinal micro biota and stimulate selectively the growth and/or activity of intestinal bacteria associated with health and well-being. (Gibson et al. 2004). previous research findings have shown that the beneficial effects of probiotics can manifest as enhanced feed utilization of cultured aquatic animals through the supplementation of digestive enzymes, improved feed efficiency and higher growth, the prevention of intestinal disorders and the predigestion of antinutritional factors present in mixed feed (Balcazar et al., 2006; Suzer et al., 2008).

Some researchers have suggested that microorganisms have a beneficial effect in the digestive processes of aquatic animals. In fish, it has been reported that Bacteroides and Clostridium sp. have contributed to the host's nutrition, especially by supplying fatty acids and vitamins (Sakata, 1990). Some microorganisms such as Agrobacterium sp., Pseudomonas sp., Brevi-bacterium sp., Microbacterium sp., and Staphylococcus sp. may contribute to nutritional processes in Salvelinus alpinus L (Ringø et al. 1995).

The present study demonstrated that the addition of prebiotic and probiotic in different levels to diet improves the growth performance of carp larval. Fish fed prebiotic and prebiotic displayed significantly increased in SGR, BWI and GR (Except treatment 6 that there was no significant difference between treatment 6 and control group in SGR, BWI and GR). This growth improvement can cause by positive effect this probiotic on digestive system flora, stimulating production of digestive enzymes and increase digestive ratio and absorption used food (Welker and Lim, 2011).

Salamatdoustnobar et al. (2011) reported that FCR and SGR significantly affected in fingerling rainbow trout fed prebiotic (Saccharomyces cerevisiae) (Salamtdoust et al.
2011). Study on use of prebiotic in diet of Siberian sturgeon (Acipenser baerii) showed that prebiotic supplementation improved growth and SGR (Mahious, 2005). This result was in garmented with our result that demonstrated there was correlation between prebiotic and FCR and SGR. Khattab et al. (2005) reported that tilapia (Oreochromis niloticus) fed probiotic displayed significantly improved in FCR, that the highest FCR was detected in control group (no probiotic). In our study, similar results were observed. In the present study, there was significant difference between treatments and control group in FCR $(p<0.05)$. The lower FCR indicate the positive role of probiotic and prebiotic on improving food digestion.

Abdel-Tawwab et al. (2008) suggested that yeast supplementation played a role in enhancing food intake with a subsequent enhancement of fish body composition. Moreover, due to the nutrient utilization and the high nutrient digestibility, the deposited nutrients increased. On the other hand, changes in protein and lipid content in fish body could be linked with changes in their synthesis, deposition rate in muscle and/or different growth rate (Smith, 1981; AbdelTawwab et al. 2008).

In the present study, carp larval fed probiotic premalac showed significantly improved in Moisture, Ash, crud Protein and fat $(\mathrm{P}<0.05)$. However, There was no significant difference detected between treatments 1, 2 and control group in crud Protein $(\mathrm{p}>0 / 05)$. This results in garmented with Farzanfar (2007)

In generally, the best performance of fish in terms of growth performance and feed utilisation efficiency was recorded at the prebiotic and probiotic in diet.The beneficial effect of probiotic Primalac and prebiotiv immonowall on the feeding efficiency of carp larval was completely observed. Therefore, we recommend premalac and immnowall (dose of 1 and $15 \%$ ) be added at the beginning of the period of carp larval culture to improve the growth and survival.

\section{Acknowledgments}

The authors would like to thank, Mr. Mirzaman Ramezani, experts and colleagues of the Propagation Center, breeding and restocking fish Shahid Rajai Sari (Iran) for providing the necessary facilities for the study.

\section{References}

[1] Abdel-Tawwab, M., Abdel-Rahman, A.M. and Ismael, N.E.M., 2008. Evaluation of commercial live bakers' yeast, Saccharomyces cerevisiae as a growth and immunity promoter for fry Nile tilapia, Oreochromis niloticus (L.) challenged in situ with Aeromonas hydrophila. Aquaculture. 280:185-189.

[2] Afshar Mazandaran, N. 2003. Guidelines for aquatic animal feeding operations and inputs of food and medicine in Iran. Deputy breeding and Bzyan.antsharat Smarng. 216pp.

[3] Balcazar, J.L., I. de Blas, I. Ruiz-Zarzuela, D. Cunningham, D. Vendrell and J.L. Muzquiz, 2006. The role of probiotics in aquaculture. Review. Veterinary Microbiology, 114:173-186. 


\section{International Journal of Science and Research (IJSR) \\ ISSN (Online): 2319-7064}

Index Copernicus Value (2013): 6.14 | Impact Factor (2015): 6.391

[4] El-Haroun, E.R., A.M.A.S.Goda and M.A.K. Chowdhury, 2006. Effect of dietary probiotic Biogens supplementation as a growth promoter on growth performance and feed utilization of Nile tilapia Oreochromis niloticus (L.). Aquaculture Research, 37:1473-1480

[5] Emadi, H. . Kutum victim of weak management. Aquatic Magazine. 7. 40-46.

[6] Farzanfar, A., Lashto Aghaei, G., Alizadeh, M., Bayati, M., Ghorban, R., 2007. Study on growth performance of Rainbow trout, Oncorhynchus mykiss, larvae with different concentration of probiotic in diet. Aquaculture .vol. 80, 147-153.

[7] Fuller, R., 1989. Probiotics in man and animals. Journal Applied Bacteriology. 66, 365-378.

[8] Gibson G.R., H.M. Probert, J.V. Loo, R.A. Rastall and M.B. Roberfroid, 2004. Nutrition Research Reviews, 17: 259-275.

[9] GIBSON, G. R., A. RASTALL R and R. FULLER, 2003. The health benefi ts of probiotics and prebiotics. In: Fuller R., Perdigon G. (Eds.), Gut Flora, Nutrition, Immunity and Health. Blackwell Publishing Ltd, Oxford, UK, pp: 52-76.

[10]Gibson, G.R., Roberfroid, B., 1999. Dietary modulation of the human colonic microbiota: introducing the concept of prebiotics. Journal of Nutrition. 125,1401-1412.

[11] Girri,S.S;Sahoo,K;Sahu.B.B;Sahu,A.K;Mohanty,S.N; Mohanty,P.K;and Ayyappan,S;2002. Dietary modulation of the human colonic microbiota: introducing the concept of prebiotics. Journal of Nutrition. 125: 1401-1412.

[12] Hung, S.S.O; lutes, P.B. and Storebakken , T ; 1989. Growth and feed efficiency of whitesturgeon (Acipenser transmontanus) sub yearling at different feeding rates . Aquaculture .vol. 80, 147-153.

[13] Mahious A.S and Frans Ollvier . (2005) . Effect of dietery inulin and oligosaccharides as prebiotics for weaning turbot, psetta maxima . Aquaculture international. 25, 37-46.

[14] Mohapatra, S., T. Chakraborty, A.K. Prusty, P. Das, K. Paniprasad and K.N. Mohanta, 2012. Use of probiotics in the diet of rohu, Labeo rohita fingerlings: effects on growth nutrient digestibility, retention digestive enzyme activities and intestinal microflra. Aquaculture Nutrition, 18:1-11

[15] Peng, A and Gatlin,S 2003 . The role of probiotics in aquaculture. Veterinary Microbiology. 114, 173-186.

[16]Ringø E, Strøm E, Tabachek JA (1995) Intestinal microflora of salmonids: a review. Aquaculture Research 26: 773-789.

[17] Ronyai , A; peteri , A . and Radics , F; 1990 . Cross breeding of starlet and lena river sturgeon. Aquaculture. Hungrica szarwas.vol .6, 13-18.

[18] Sakata T (1990) Microflora in the digestive tract of fish and shellfish. Proceedings of the International Symposium on Microbiology in Poecilotherms: 171176.

[19] Salamatdoustnobar, R., A. Ghorbani, S.S. Ghaem magami and V. Motalebi, 2011. World Journal of Fish and Marine Scince, 3(4): 305-307.

[20] Smith, M.A.K., 1981. Estimation of growth potential by measurement of tissue protein synthetic rates in feeding and fasting rainbow trout, Salmo gairdneri Richardson. Journal of Fish Biology. 19:213-220.

[21] Suzer, C., D. Coban, H.O. Kamaci, S. Saka, K. Firat, O. Otgucuoglu and H. Kucuksari, 2008. Lactobacillus spp. bacteria as probiotics in gilthead sea bream (Sparus aurata, L.) larvae: Effects on growth performance and digestive enzyme activities. Aquaculture, 280:140-145.

[22] Verschuere, L., Rombout, G., Sorgeloos, P., Verstraete, W., 2000. Probiotic Bacteria as Biological Control Agents in Aquaculture. Microbiology And Molecular Biology Reviews. 64, 655-671.

[23] Welker, T.L. and Lim, C., 2011. Use of probiotics in diets of tilapia. Journal of Aquauclture Research and Development. S1:014. doi:10.4172/2155- 9546.S1-014. 